\title{
Quality characteristics of fermented vinegar prepared with the detoxified Rhus verniciflua extract
}

\author{
Seong Yeol Baek ${ }^{1}$, Choong Hwan Lee ${ }^{2}$, Yoo Kyoung Park ${ }^{3}$, Han-Seok Choi ${ }^{1}$, \\ Ji-Young Mun ${ }^{1}$, Soo-Hwan Yeo ${ }^{1 *}$ \\ ${ }^{1}$ Department of Agro-food Resources, National Institute of Agricultural Sciences, RDA, Wanju 55365, Republic of Korea \\ ${ }^{2}$ Department of Bioscience and Biotechnology, Konkuk University, Seoul 05029, Republic of Korea \\ ${ }^{3}$ Department of Medical Nutrition, Kyunghee University, Yongin 17104, Republic of Korea
}

\section{무독화 옻 추출물로 제조한 발효식초의 품질 특성}

\author{
백성열 $^{1} \cdot$ 이충환 ${ }^{2} \cdot$ 박유경 $^{3} \cdot$ 최한석 ${ }^{1} \cdot$ 문지영 $^{1} \cdot$ 여수환 $^{1 *}$ \\ ${ }^{1}$ 농촌진흥청 국립농업과학원 농식품자원부 \\ ${ }^{2}$ 건국대학교 생명공학과, ${ }^{3}$ 경희대학교 의학영양학과
}

\begin{abstract}
In this study, vinegar was produced using urushiol-free fermented Rhus verniciflua extract to create a lacquer with added value. The effect of manufacturing conditions on the quality of vinegar using detoxified $R$. verniciflua extract for fermentation was investigated. The acidity of the vinegar for inoculations with various liquid starter contents was $4.8 \sim 4.9 \%$, and it was similar among all treatment groups. The acidity of vinegar was higher when the initial alcohol content was high. The acetic acid yields were $82.8 \%, 84.4 \%, 77.7 \%$, and $69.5 \%$, and the maximum yield was observed when the initial alcohol content was $6 \%$. For acetic acid fermentation using different amounts of detoxified $\boldsymbol{R}$. verniciflua extracts, the acidity of the vinegar with the extract after fermentation was $5.3 \sim 5.9 \%$. However, the acidity of vinegar without the extract was $5.5 \%$. The intensity of the brown color was high for vinegar without the extract. Hunter's $L$ values were high for vinegar with an extract content of $2 \%$. Acetic acid $(53.3 \sim 65.8 \mathrm{mg} / \mathrm{mL})$ was the predominant acid. Arginine $(190.3 \sim 333.3 \mu \mathrm{g} / \mathrm{mL})$, proline $(125.6 \sim 290.8 \mu \mathrm{g} / \mathrm{mL})$, alanine $(126.1 \sim 270.9 \mu \mathrm{g} / \mathrm{mL})$, and glutamic acid $(159.0 \sim 262.4 \mu \mathrm{g} / \mathrm{mL})$ were the predominant amino acids in detoxified $R$. verniciflua vinegar.
\end{abstract}

Key words : vinegar, Rhus verniciflua, fermentation, acidity, liquid starter

\section{서 론}

식초는 식생활사에서 오랜 역사를 지닌 중요한 전통 발 효식품으로 최근 여러 가지 효능이 과학적으로 규명되면서 식초 소비량은 점차 증가되고 있다. 주로 조미 용도로 사용 된 식초는 프리미엄급 식초 음료 등의 다양한 기능성 소재 뿐만 아니라 건강식품으로도 관심이 높아지고 있다(1). 또

*Corresponding author. E-mail : yeobio@korea.kr Phone : 82-63-238-3610, Fax : 82-63-238-3843

Received 15 July 2015; Revised 19 August 2015; Accepted 21 August 2015.

Copyright (c) The Korean Society of Food Preservation. All rights reserved.
한 식초는 대표적인 알칼리성 식품으로 동맥경화 예방과 부신피질 호르몬의 분비, 소화 촉진, 당뇨병과 비만, 혈압 상승, 노화방지와 항종양 효과 등의 뛰어난 기능성에 주목 을 받고 있다 $(2,3)$.

식초는 소량의 휘발성 및 비휘발성의 유기산, 당류, 아미 노산, 에스테르 등을 함유한 독특한 방향과 신맛을 가진 대표적인 발효식품이다. 특히, 음식을 조리할 때 신맛을 내는 조미료로 사용되면서 짠맛과 단맛의 음식 맛을 부드럽 게 하며 특유의 향미를 더해 줄 뿐만 아니라, 생선의 비린내 를 감소시키고, 육류를 연하게 하는 등 조리에 다양하게 사용되고 있다. 최근에는 소스, 마요네즈, 드레싱, 케첩의 원료와 향미재로도 이용되고 있다(4). 식초는 제조방법에 따라 발효과정을 거치는 발효식초와 빙초산 또는 초산을 
먹는물로 희석한 희석초산으로 구분된다. 국내에서는 식초 를 총산 4 20\%(감식초는 2.6이상)로 규정하고 있으며, 식초 를 발효식초, 희석식초, 기타식초로 유형을 분류하고 있어 서 시판되는 식초의 경우 다양한 원료 사용량과 제조방법에 따라 최종 제품의 품질에 큰 차이가 있다(5).

옻은 수포, 가려움, 발진 등의 접촉성 피부염을 유발하는 우루시올(urushiol) 성분을 가지고 있으나 당뇨병과 위장병 치료를 위해 전통적으로 닭과 오리 등을 조리할 때 첨가하 여 먹어왔다(6). 옻에 함유된 폴리페놀 및 플라보노이드 성분은 항산화(7-9), 항돌연변이(10), 항염증(11,12) 및 항균 과 a-glucosidase 억제 효과(13) 등이 있는 것으로 보고되어 있다.

최근 옻이 고부가가치 산업으로 인식되면서 식의약소재 로 이용하려는 시도가 증가되고 있다. 충청북도 옥천군과 강원도 원주시는 지식경제부로부터 각각 2005년과 2006년 에 옻 산업특구로 지정받았고, 지역 농촌관광과 연계되면 서 옻에 대한 국민적 관심이 높아지고 있다. 국내 옻나무 생산 면적은 2002년 1,216 천 $\mathrm{m}^{2}$ 에서 2007년 3,058천 $\mathrm{m}^{2}$ 으로 약 2.5 배 증가하였고, 식용 판매액 비중도 2002년 $52.5 \%$ 에 서 2007년 75.8\%로 증가하였다(14). 식품의약품안전처에 서는 2004년 알레르기(allergy) 유발 성분인 우루시올이 제 거된 옻 추출물로 옻닭 및 옻오리에 식용으로 사용할 수 있도록 규제를 완화하였다. 2013년에는 본 연구진(15)에 의해 아까시재목버섯(장수버섯, Fomitella fraxinea)을 이용 하여 우루시올 성분을 제거한 옻나무 추출물로 장류, 발효 식초, 탁주, 약주, 청주 및 과실주에 한하여 발효공정 전에만 사용할 수 있도록 옻의 기준과 규격이 개정되었다(5). 현재 온오프라인에서 무독화 옻 추출물을 이용한 다양한 형태의 제품들이 판매되고 있다.

따라서, 본 연구에서는 옻의 산업적 활용성 및 농산업체 의 부가가치 증대를 위한 다양한 옻 가공품 개발의 일환으 로 아까시재목버섯에 의해 우루시올 성분이 제거된 무독화 옻 추출물을 첨가한 식초의 품질 특성을 조사하였다.

\section{재료 및 방법}

\section{무독화 발효옻 추출물 제조}

본 연구에 사용된 옻(Rhus verniciflua)은 2012년 4월 충북 옥천산 옻나무 껍질을 구입하여 사용하였으며, Choi 등(16) 의 방법에 따라 우루시올이 제거된 무독화 발효 옻 추출물 을 제조하였다. 옻나무 껍질을 $2 \times 2 \mathrm{~cm}$ 크기로 자른 후 수분 이 통할 수 있는 자루에 담아 24시간 동안 물에 담근 후, 물 빼기를 하였다. 수분이 흡수된 옻나무 껍질을 $5 \mathrm{~L}$ 버섯재 배 봉투에 옮겨 담고 필터를 달아 $121^{\circ} \mathrm{C}$ 에서 100 분간 살균 하였다. Choi 등(17)의 방법에 따라 전배양된 아까시재목버 섯 균사체를 접종하고 $21^{\circ} \mathrm{C}$ 에서 30 일간 배양한 후, $50^{\circ} \mathrm{C}$ 에
서 열풍 건조시켜 무독화 발효 옻을 제조하였다. 믹서로 잘게 갈은 옻 $1,000 \mathrm{~g}$ 에 10 배 $(\mathrm{w} / \mathrm{v})$ 의 증류수를 첨가한 후, 무게를 측정하고 고압 살균기에 넣어 $110^{\circ} \mathrm{C}$ 에서 6 시간 동안 추출한 후, 증발된 수분량을 증류수로 보정하여 동일한 무 게로 조정하였다. 발효 옻 조추출물은 광목천으로 여과하 여 사용하였다.

\section{사용균주 및 종초}

본 연구에서 사용된 알코올 발효 균주는 시판효모인 Saccharomyces cerevisiae(Fermivin, Oenobrands, France)를 YPD(yeast extract $1 \%$, peptone $2 \%$, glucose $2 \%$, agar $1.5 \%$ ) 평판 배지에 계대 배양한 후, $\mathrm{YM}$ (yeast extract $3 \%$, malt extract $3 \%$, peptone $0.5 \%$, glucose $1 \%$ ) 액체배지를 이용하여 $25^{\circ} \mathrm{C}$ 에서 24 시간 정치배양하여 사용하였다. 초산 발효를 위한 종초는 전보(18)에서 분리한 초산균 중 Acetobacter pasteurianus KACC16934 균주를 시험 배지(glucose 8.26 $\mathrm{g} / \mathrm{L}$, fructose $2.5 \mathrm{~g} / \mathrm{L}$, soy peptone $83.92 \mathrm{~g} / \mathrm{L}$, manganese sulfate $0.088 \mathrm{~g} / \mathrm{L}, \mathrm{pH} 5.7$ )에 $30^{\circ} \mathrm{C}$ 에서 72 시간 진탕배양하여 사용하였다(19).

종초는 무독화 옻 추출물을 첨가하여 알코올 발효한 발 효액을 여과한 후, 알코올 함량이 $6 \%$ 되도록 희석하여 초산 균을 접종하고 $30^{\circ} \mathrm{C}$ 에서 $200 \mathrm{rpm}$ 으로 72시간 진탕배양 (WIS-20R, DAIHAN Scientific Co., Ltd., Wonju, Korea)한 것을 종초로 사용하였다.

\section{알코올 및 초산 발효}

알코올 발효는 황국 $100 \mathrm{~g}$, 백국 $200 \mathrm{~g}$ (Chungmoo Fermentation Co., Ltd., Ulju, Korea), 물 $450 \mathrm{~mL}$ 에 효모 0.9 $\mathrm{g}$ (Fermivin, Oenobrands, France)을 첨가하였다. 무독화 옻 추출물은 가수량 $150 \%$ 에 맞추어 농도를 달리하여 첨가(무 첨가 : 옻 추출물 $0 \mathrm{~mL}$, 물 $450 \mathrm{~mL}, 2 \%$ 첨가 : 옻 추출물 $400 \mathrm{~mL}$, 물 $50 \mathrm{~mL}, 6 \%$ 첨가 : 옻 추출물 $400 \mathrm{~mL}$, 물 50 $\mathrm{mL}, 10 \%$ 첨가 : 옻 추출물 $450 \mathrm{~mL}$, 물 $0 \mathrm{~mL}$ )한 후, $25^{\circ} \mathrm{C}$ 에서 36 시간 발효하였다(1단 담금). 2 단 담금을 위해, 찹쌀 고두 밥 $600 \mathrm{~g}$, 멥쌀 고두밥 $600 \mathrm{~g}$, 개량누룩(Korea enzyme Co., Ltd., Hwaseong, Korea) $12 \mathrm{~g}$, 물 1,800 mL, 무독화 옻 추출물 을 가수량에 따라 달리 첨가(무첨가 : 옻 추출물 $0 \mathrm{~mL}$, 물 $1,800 \mathrm{~mL}, 2 \%$ 첨가 : 옻 추출물 $50 \mathrm{~mL}$, 물 $1,750 \mathrm{~mL}, 6 \%$ 첨가: 옻 추출물 $950 \mathrm{~mL}$, 물 $850 \mathrm{~mL}, 10 \%$ 첨가 : 옻 추출물 $1,800 \mathrm{~mL}$, 물 $0 \mathrm{~mL}$ )한 후, $20^{\circ} \mathrm{C}$ 에서 7 일간 발효를 하였다.

초산발효는 알코올 농도를 $5,6,7,8 \%$ 되도록 희석한 후, 종초를 $10 \%(\mathrm{v} / \mathrm{v})$ 접종하여 $30^{\circ} \mathrm{C}$ 배양기에서 정치발효를 하였다.

\section{$\mathrm{pH}$ 및 적정산도}

$\mathrm{pH}$ 는 시료 $10 \mathrm{~mL}$ 를 취하여 $\mathrm{pH}$ meter(FE20, Mettler 
Toledo, Switzerland)를 사용하였으며, 적정산도는 6배로 희 석한 시료 $5 \mathrm{~mL}$ 에 $1 \%$ 페놀프탈레인 지시약을 2 3방울 떨어뜨린 다음, $\mathrm{pH} 8.3$ 이 될 때까지 $0.1 \mathrm{~N} \mathrm{NaOH}$ 용액으로 적정하여 acetic $\operatorname{acid}(\%)$ 로 환산하였다.

\section{발효 수율}

초산 발효 수율은 총 알코올 농도에 따른 이론적인 초산 생산량에 대한 초산 생성량을 백분율로 나타내었다(20).

$$
\begin{aligned}
& \text { 초산 수율 }(\%)= \\
& \frac{\text { 최종산도 }(\%, w / v)-\text { 초기산도 }(\%, w / v)}{\text { 초기 알코올 농도 }(\%, v / v) \times 1.0} \times 100
\end{aligned}
$$

\section{갈색도 및 색도}

갈색도는 분광광도계(SYNERGY MX, BioTek, Winooski, Vermont, USA)를 이용하여 $420 \mathrm{~nm}$ 에서 측정하였고, 색도 는 색차계(Pro Hunter Lab, Reston, VA, USA)를 이용하여 $\mathrm{L}$ (명도), $\mathrm{a}$ (적색도), $\mathrm{b}$ (황색도) 값을 측정하였다.

\section{유기산 함량}

유기산 분석을 위한 전처리는 시료 $2 \mathrm{~mL}$ 를 $17,000 \mathrm{rpm}$ 에 서 15 분간 원심분리 시킨 다음, $0.45 \mu \mathrm{m}$ membrane filter(Millipore Co., Bedford, MA, USA)로 여과시키고, Sep-pak $\mathrm{C}_{18}$ cartridge(Waters Oasis, Milford, MA, USA)로 색소를 제거하였다. 시료는 HPLC(Chromaster 5000, Hitachi, Ltd., Tokyo, Japan)로 분석하였으며, ODS-100W(4.6 $\mathrm{mm} \times 250 \mathrm{~mm}$ ) column을 사용하여 분석하였다. 이동상은 $3 \mathrm{mM}$ perchloric acid를 사용하였으며, flow rate는 0.7 $\mathrm{mL} / \mathrm{min}$, column oven의 온도는 $63^{\circ} \mathrm{C}$ 로 하였다. 분리물을 반응액 $\left(0.2 \mathrm{mM}\right.$ bromothymol blue, $15 \mathrm{mM} \mathrm{Na} \mathrm{HPO}_{4}, 2 \mathrm{mM}$ $\mathrm{NaOH}$ 과 혼합시킨 후, $\mathrm{UV} 440 \mathrm{~nm}$ 에서 검출하였다. 이때 반응액의 flow rate는 $0.9 \mathrm{~mL} / \mathrm{min}$ 로 하였다.

\section{유리 아미노산 함량}

식초 발효액의 유리 아미노산 정량은 시료 $5 \mathrm{~mL}$ 에 0.02 $\mathrm{N} \mathrm{HCl}$ 을 20배 희석한 후, $0.2 \mu \mathrm{m}$ 시린지 필터로 여과하여 amino acid analyzer(L-8900, Hitachi Co., Tokyo, Japan)로 분석하였다(21).

\section{통계분석}

시료 분석은 3 회 반복하여 실험군당 평균과 표준편차로 나타내었다. 발효 수율은 SPSS(12.0, SPSS Inc., Chicago, $\mathrm{IL}, \mathrm{USA})$ 통계 프로그램을 이용하여 일원배치분산분석 (one-way ANOVA test)을 하고 $\mathrm{p}<0.05$ 수준에서 Duncan's multiple range test(DMRT)로 평균 간의 다중비교를 실시하 였다.

\section{결과 및 고찰}

\section{종초 접종량에 따른 초산 발효의 특성}

$A$ pasteurianus $\mathrm{KACC} 16934$ 로 제조한 종초의 접종량(5, $10,15,20 \%)$ 에 따라 초산 발효에 미치는 결과를 Fig. 2 에 나타내었다. 접종량이 다른 4종류의 종초를 접종하여 초산 발효를 종료한 후, 접종량에 따른 산도를 측정한 결과 4.8 4.9로 시험구간의 현저한 차이는 나타나지 않았다. 그 러나 발효 초기, 종초 접종량에 따른 초기 산도의 차이가 있었으나 발효가 진행됨에 따라 그 차이는 줄어드는 것으로 나타났다. 오히려 종초 5\%을 접종한 시험구에서 발효 시기 별 산도의 그래프가 더욱 경사진 것으로 나타나 초산 발효 의 속도가 높았으며, 종초 접종량에 따른 산도의 차이는 미미하여 초산 발효시 종초를 5 10\% 첨가하는 것이 효율적 이라고 생각된다. 또한 $\operatorname{Kim}$ 등(2)은 무화과 식초 제조 연구 에서 종초 접종량을 $2.5 \sim 10 \%$ 로 조절하여 초산 생성 량을 검토한 결과, 시험구간에 따른 현저한 차이는 없었으며, $5 \%$ 정도 종초를 접종하여도 충분하다고 보고하였다. 종초 접종량에 따른 $\mathrm{pH}$ 의 변화는 산도의 변화에 감소하였으며, 발효 후기에는 종초 접종량에 따른 $\mathrm{pH}$ 의 차이는 보이지 않았다.

\section{초기 알코올 농도에 따른 초산 발효의 특성}

무독화 옻식초 제조시, 초기 알코올 농도 $(5,6,7,8 \%)$ 에 따라 초산 발효에 미치는 결과를 Fig. 3에 나타내었다. 초산 발효 초기 $\mathrm{pH}$ 는 3.5 3.6으로 나타났고 발효가 진행됨에 따라 꾸준히 감소하여 발효 7일째 2.8 2.9였으며, 그 이후에 는 거의 변화가 없었다. 알코올 함량이 높을수록 $\mathrm{pH}$ 가 조금 높게 나타났으나 그 차이는 크지 않았다. 초산 발효시 $\mathrm{pH}$ 는 발효 초기(1 3일)에 큰 폭으로 감소하여 초산 발효가 활발 히 일어나는 것으로 나타났다. 발효 초기 적정산도는 $0.5 \sim 0.6 \%$ 이었으나 발효 3일째 큰 폭으로 상승하였으며 발 효 9일째 알코올 농도에 따라 산도는 4.6 6.2\%로 나타났다. 일반적으로 초산 발효는 알코올 농도에 큰 영향을 받기 때문에 초산 발효의 에너지원으로써 필요한 알코올의 최적 농도 설정은 매우 중요하다. Fig. 3과 같이 알코올 함량이 $5 \%$ 인 경우, 발효 3 일째 적정산도가 $4.5 \%$ 로 나타났고 그 이후에는 거의 변화가 없었다. 반면 알코올 함량이 $8 \%$ 인 경우, 발효 3 일째 적정산도가 $3.4 \%$ 로 가장 낮았지만 발효기 간이 경과되면서 초산균이 알코올을 소비하여 최종 $6.2 \%$ 까 지 나타났다. 알코올 함량이 $8 \%$ 인 시험구는 발효 초기에 초산 발효가 다른 시험구에 비해 늦었는데 이는 높은 알코 올 농도로 인해 발효 유도가 저해된 것으로 보인다. 이는 기질인 알코올 농도가 적정농도 이하와 이상에서 정상적인 발효가 유도되지 않았으며, 특히 고농도 알코올에 대한 내 성 약화로 초산균의 증식과 발효 유도가 어려운 것으로 여겨진다. $\operatorname{Kim}$ 등(22)의 연구에서도 초기 알코올 농도가 
$8 \%$ 일 때, 초산 발효 속도가 지연된다고 보고한 바 있다. 따라서 식초 제조시 기질로 사용하는 초기 알코올 농도가 너무 높으면 초산균의 산 생성능이 저해됨을 알 수 있었다. 본 연구의 $\mathrm{pH}$ 와 적정산도의 결과로 보아 무독화 옻식초의 초산 발효는 초기 알코올 농도가 다른 조건에서도 발효 초기에 활발하게 이루어지는 것으로 나타났다. 본 연구에 서는 무독화 옻 추출물이 첨가된 식초이지만, 감 등 다른 첨가물을 이용한 발효식초 연구에서 초산 발효후의 $\mathrm{pH}$ 는 대부분 2.8 3.1 사이로 보고되었다 $(23,24)$. 또한 적정산도는 초기 알코올 농도에 따라 4 7\% 사이로 나타났다 $(25,26)$. 그리고 $\operatorname{Kim}$ 등(27)의 매실을 이용한 식초 연구에서는 $6 \%$ 알코올 첨가구에서 발효 7일째 $6.5 \%$ 로 가장 높은 산도를 나타내었으며, $8 \%$ 와 $10 \%$ 첨가구에서는 오히려 산도가 낮 아 초기 알코올 함량이 $6 \%$ 일 때 초산 발효가 가장 효과적으 로 일어난다고 보고하였다. $\mathrm{Oh}(28)$ 의 배식초 발효조건에서 도 초기 알코올 농도를 $4,6,8,10 \%$ 로 달리하여 초산발효를 하였을 때, 최적 알코올 농도는 $8 \%$ 이었고, $10 \%$ 알코올 농도 에서는 초산 발효 속도가 느리며, 수율도 $68 \%$ 로 좋지 않은 것으로 보고되었다.

초산 변환 수율은 각각 $82.8 \%, 84.4 \%, 77.7 \%$ 및 $69.5 \%$ 로, 초기 알코올 농도가 $6 \%$ 시험구에서 가장 높았으며, 알코올 농도 $8 \%$ 시험구에서 가장 낮은 것으로 나타나 초산 발효가 저해되는 것으로 여겨진다(Table 1). 알코올이 초산으로 전 환되는 비율인 발효 수율은 이론적으로는 알코올 중량의 1.64 배 초산이 생성되지만 실험결과는 이론치의 88 90\% 효율을 나타내는데 이러한 이유는 발효과정 중 알코올의

Table 1. Effect of initial alcohol content on the detoxified Rhus verniciflua vinegar production yield

\begin{tabular}{ccccc}
\hline & \multicolumn{4}{c}{ Initial alcohol content (\%) } \\
\cline { 2 - 5 } & 5 & 6 & 7 & 8 \\
\hline $\begin{array}{c}\text { Acetic acid } \\
\text { fermentation } \\
\text { yield (\%) }\end{array}$ & $82.8 \pm 5.52^{\mathrm{al})}$ & $84.4 \pm 4.92^{\mathrm{a}}$ & $77.7 \pm 7.88^{\mathrm{ab}}$ & $69.5 \pm 7.08^{\mathrm{b}}$ \\
\hline
\end{tabular}

${ }^{1)}$ Mean \pm SD ( $n=3$ ) within each column followed by the same letter are not significantly different $(\mathrm{p}<0.05)$.
증발과 초산 이외의 다른 물질로 전환되는 것으로 알려져 있다(29). Woo 등(30)이 보고한 고산도 포도식초 발효 연구 에서 초기 알코올 $6 \%$ 시험구에서 초산 수율이 $70.3 \%$ 로 가장 높게 나타난 결과와 유사하였다. 따라서 본 연구의 무독화 옻식초 제조에서는 초기 알코올 최적 농도를 $6 \%$ 로 설정하였다.

\section{무독화 옻 추출물 첨가 농도에 따른 초산 발효의 특성}

무독화 옻 추출물의 첨가 농도 $(0,2,6,10 \%)$ 에 따라 초산 발효에 미치는 결과를 Fig. 1에 나타내었다. 옻 추출물 $10 \%$ 를 첨가한 시험구가 발효 3일에서 7일차에 빠른 초산 발효 가 진행되어 산도가 $5.3 \%$ 로 증가하였다. 옻 추출물 $2,6 \%$ 첨가 시험구는 각각 $5.7 \%, 5.9 \%$ 의 산도를 나타내었다. 무첨 가 시험구는 산도가 $5.5 \%$ 로 무독화 옻 추출물 첨가구에 비해 산도가 $0.2 \sim 0.4 \%$ 낮았다. 무독화 옻 추출물의 첨가 농도에 따른 산도의 차이는 크지 않았지만 무독화 옻 추출 물 첨가군이 무첨가군보다 초산균의 증식을 유도함으로써 초산 발효를 촉진시키는 것으로 여겨진다. Choi 등(16)의 연구에서 발효옻 추출물은 항균활성이 없으며 오히려 Bacillus 속 미생물의 균체 성장을 큰 폭으로 증가시킨다고 보고하였다. 무독화 옻 추출물에는 항균활성이 높은 우루 시올 성분이 없어 균체 성장에 영향을 주는 탄소원, 질소원 및 무기물 등의 미량 요소 영향으로 발효미생물의 증식이 무첨가군보다 더 증가하는 것으로 알려져 있다. 무독화 옻 추출물 농도에 따른 초산 발효시 $\mathrm{pH}$ 변화는 발효 전후의 차이는 크지 않았다.

\section{무독화 옻 추출물 첨가 농도에 따른 갈색도 및 색도 변화}

무독화 옻 추출물 농도를 달리하여 제조한 무독화 옻식 초의 갈색도 및 색도 분석 결과를 Table 2에 나타내었다. 무독화 옻 추출물 무첨가 식초의 갈색도는 0.52 로 옻 추출물 첨가 시험구(0.29 0.37)보다 갈색의 정도가 진하게 나타났 다. 옻 추출물 무첨가 식초의 색도는 발효 초기보다 명도값 이 37.66 으로 낮아졌으며, 적색도와 황색도는 각각 6.2, 16.93 으로 높아졌다. 무독화 옻 추출물 첨가 농도에 따른

Table 2. Comparison of the brown color intensity and Hunter's color value between detoxified Rhus verniciflua extracts with different concentrations in vinegar after static fermentation

\begin{tabular}{|c|c|c|c|c|c|c|c|c|}
\hline \multirow{3}{*}{$\begin{array}{l}\text { Extract content } \\
\quad(\%)\end{array}$} & \multirow{2}{*}{\multicolumn{2}{|c|}{$\begin{array}{l}\text { Brown color intensity } \\
\text { (OD at } 420 \mathrm{~nm} \text { ) }\end{array}$}} & \multicolumn{6}{|c|}{ Hunter's color value ${ }^{1)}$} \\
\hline & & & \multicolumn{2}{|c|}{$\mathrm{L}$} & \multicolumn{2}{|c|}{$\mathrm{a}$} & \multicolumn{2}{|c|}{$\mathrm{b}$} \\
\hline & 0 day & 9 day & 0 day & 9 day & 0 day & 9 day & 0 day & 9 day \\
\hline 0 & $0.079 \pm 0.04^{2)}$ & $0.52 \pm 0.11$ & $86.26 \pm 4.72$ & $37.66 \pm 1.34$ & $0.04 \pm 0.22$ & $6.20 \pm 0.27$ & $4.82 \pm 0.84$ & $16.93 \pm 0.90$ \\
\hline 2 & $0.072 \pm 0.02$ & $0.32 \pm 0.05$ & $89.05 \pm 2.77$ & $61.12 \pm 2.62$ & $-0.34 \pm 0.17$ & $4.27 \pm 0.07$ & $7.92 \pm 0.69$ & $19.95 \pm 0.42$ \\
\hline 6 & $0.07 \pm 0.02$ & $0.37 \pm 0.13$ & $90.25 \pm 3.81$ & $54.82 \pm 2.35$ & $-0.45 \pm 0.22$ & $5.40 \pm 0.76$ & $8.65 \pm 0.72$ & $21.46 \pm 1.16$ \\
\hline 10 & $0.211 \pm 0.02$ & $0.29 \pm 0.02$ & $71.84 \pm 9.34$ & $38.96 \pm 15.59$ & $0.13 \pm 0.46$ & $4.75 \pm 0.85$ & $9.19 \pm 1.00$ & $16.01 \pm 3.00$ \\
\hline
\end{tabular}

${ }^{11} \mathrm{~L}$, degree of lightness (white $+100 \leftrightarrow 0$ black); a, degree of redness (red $+100 \leftrightarrow 0 \leftrightarrow-80$ green); b, degree of yellowness (yellow $+70 \leftrightarrow 0 \leftrightarrow-80$ blue).

${ }^{2)}$ Values represent the mean $\pm \mathrm{SD}(\mathrm{n}=3)$. 


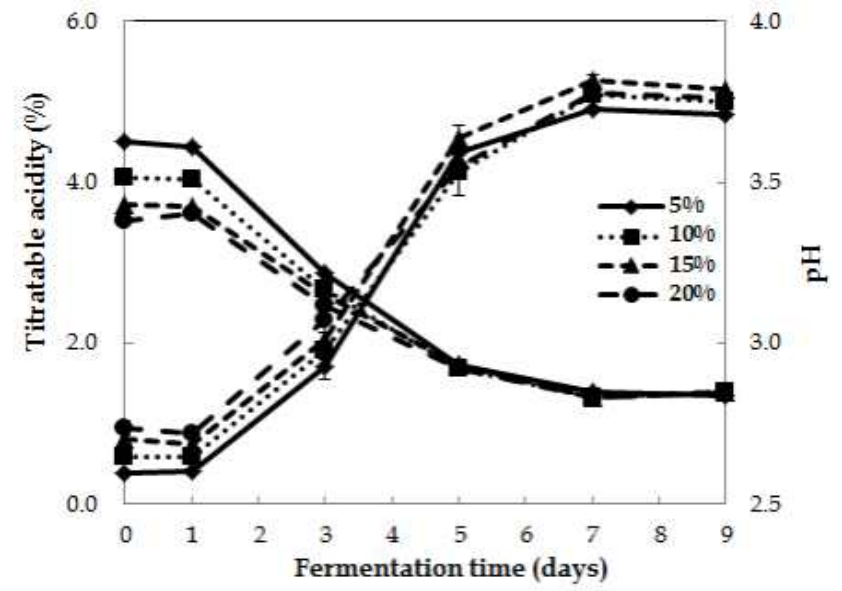

Fig 1. Change in titratable acidity and $\mathrm{pH}$ in acetic fermentation for inoculations of vinegar liquid starter at various concentration.

The detoxified Rhus verniciflua vinegar was fermented by static method at $30^{\circ} \mathrm{C}$ for 9 days (content of detoxified Rhus verniciflua extract : $2 \%$, initial alcohol concentration : 6\%). The vinegar starter was grown by shaking method on alcoholic beverage containing detoxified Rhus verniciflua extract at $30^{\circ} \mathrm{C}$ for $72 \mathrm{hr}$.

식초의 색도는 첨가 농도가 증가할수록 명도값이 낮아졌으 며, 적색도와 황색도는 첨가 농도에 따른 상관관계를 보이 지 않았다. 옻 추출물 농도 $2 \%$ 첨가 식초의 명도값이 61.12 로 가장 높게 나타났다. Lee 등(31)의 누룩첨가량에 따른 현미식초의 색도에서 명도값은 70.1 90.7로 보고하였는데 이는 사용 원료에 따른 차이로 보인다.

\section{무독화 옻 추출물 첨가 농도에 따른 유기산}

무독화 옻 추출물 농도를 달리하여 제조한 무독화 옻식 초의 유기산 분석 결과를 Table 3에 나타내었다. 검출된 주요 유기산은 acetic acid로 분석되었으며 함량은 $53.3 \sim 65.8 \mathrm{mg} / \mathrm{mL}$ 의 범위를 나타내었다. 주성분인 acetic acid는 1,695 3,839 mg\%를 나타내어 Joo 등(32)이 발효 방 법 및 원료 함량에 따라 제조한 현미식초의 초산이 2.5 3.7\%로 보고한 결과보다 높은 경향을 나타내었다. 유 기산은 식초의 산미와 지미 품질에 중요한 영향을 끼치며 $\mathrm{TCA}$ 회로를 활성화하여 젖산 분해를 촉진하는 기능성이 보고되어 있다(33). 또한 oxalic, lactic, succinic, malic, citric, tartaric acid 등 다양한 유기산이 존재하는 것으로 보고되었
다(34). Woo 등(34)은 국내 시판 현미식초에서 malic acid 검출하였는데 이는 식초의 풍미를 향상시키는 것으로 함량 이 41 120 mg\%로 보고하였고, 포도과즙을 이용한 고산도 식초의 경우, malic acid가 $305.2 \sim 317.4 \mathrm{mg} \%$, citric acid가 $279.9 \sim 311.7 \mathrm{mg} \%$, tartaric acid는 $223.4 \sim 228.1 \mathrm{mg} \%$ 가 검출 되었다(35). 포도식초에서 이러한 유기산 함량이 높은 것은 포도 원료 자체의 유기산 함량, 원료 희석 방법 및 알코올, 초산 발효과정에 따른 차이이며(35), 곡물식초의 경우는 곡물의 함량과 발효 방법에 따라 유기산 조성에 차이가 있다고 보고하였다(36). 그러나 본 연구에서 acetic acid 외 에 다른 유기산은 검출되지 않았다. 이는 유기산 분석 방법 의 차이로 생각된다. 그리고 식초는 숙성과정에서 과산화 되면서 적정산도의 감소와 유기산의 변화가 일어나 식초의 품질이 저하됨으로 이에 관한 장기적인 연구 수행이 필요하 다.

\section{무독화 옻 추출물 첨가 농도에 따른 유리아미노산}

무독화 옻 추출물 농도를 달리하여 제조한 옻식초의 유 리 아미노산 분석 결과를 Table 4에 나타내었다. 무독화 옻식초의 유리 아미노산은 33 종이 검출되었으며, 옻 추출 물의 농도가 $2 \%$ 일 때 유리 아미노산 함량이 $3455.26 \mathrm{\mu g} / \mathrm{mL}$ 로 가장 높게 나타났다. 옻 추출물 무첨가 식초는 $2,858.15$ $\mu \mathrm{g} / \mathrm{mL}$ 로 옻 추출물 $6 \%$ 첨가 시험구 $(2,877.46 \mu \mathrm{g} / \mathrm{mL})$ 와 유 리 아미노산 함량이 비슷하였으며, 옻 추출물 $10 \%$ 첨가 시험구 $(1,592.05 \mu \mathrm{g} / \mathrm{mL})$ 보다 높게 나타났다. 무독화 옻식초 의 주요 아미노산은 $\operatorname{arginine}(190.3 \sim 333.3 \mu \mathrm{g} / \mathrm{mL})$, proline $(125.6 \sim 290.8 \mu \mathrm{g} / \mathrm{mL})$, alanine $(126.1 \sim 270.9 \mu \mathrm{g} / \mathrm{mL})$, glutamic acid(159.0 262.4 $\mathrm{\mu g} / \mathrm{mL})$ 이며, 무첨가 식초에 비해 높은 유리 아미노산은 alanine과 glutamic acid로 나타났다. Joo 등(32)은 발효 방법 및 원료 함량에 따라 제조한 현미식 초의 유리 아미노산 함량이 $851 \sim 6,088 \mathrm{mg} / \mathrm{L}$ 로 누룩을 첨가 하였을 때, 높은 유리 아미노산 함량을 나타내었으며, 본 연구 결과와는 차이가 있었다. 일반적으로 식초의 아미노 산 함량의 차이는 초산균의 종류, 사용 원료, 도정, 알코올 발효 조건 등에 따라 차이가 있는 것으로 알려져 있다(36).

Table 3. Organic acid contents using different detoxified Rhus verniciflua extract concentrations in vinegar after static fermentation

(Unit : $\mathrm{mg} / \mathrm{mL}$ )

\begin{tabular}{cccccccc}
\hline $\begin{array}{c}\text { Extract content } \\
(\%)\end{array}$ & Oxalic acid & Malic acid & Lactic acid & Acetic acid & Citric acid & Succinic acid \\
\hline 0 & nd & nd & nd & $63.14 \pm 2.12^{1)}$ & nd & nd \\
2 & nd & nd & nd & $65.80 \pm 2.06$ & nd & nd \\
6 & nd & nd & nd & $61.66 \pm 0.44$ & nd & nd \\
10 & nd & nd & nd & $53.32 \pm 2.99$ & nd & nd \\
\hline
\end{tabular}

\footnotetext{
${ }^{1)}$ Values represent the mean $\pm \mathrm{SD}(\mathrm{n}=3)$.
}

${ }^{2)}$ nd, not detected. 
Table 4. Free amino acid contents using different detoxified Rhus verniciflua extract concentrations in vinegar after static fermentation

\begin{tabular}{|c|c|c|c|c|c|}
\hline & \multirow{2}{*}{ Free amino acid } & \multicolumn{4}{|c|}{ Extract content $(\%)$} \\
\hline & & 0 & 2 & 6 & 10 \\
\hline \multirow{8}{*}{$\begin{array}{c}\text { Essential } \\
\text { amino acid }\end{array}$} & Threonine & 51.98 & 57.77 & 53.32 & 28.13 \\
\hline & Valine & 105.14 & 115.49 & 104.32 & 66.46 \\
\hline & Methionine & 59.15 & 56.88 & 46.03 & 15.13 \\
\hline & Isoleucine & 74.07 & 81.04 & 70.29 & 47.44 \\
\hline & Leucine & 176.53 & 189.76 & 163.85 & 108.37 \\
\hline & Phenylalanine & 155.09 & 169.29 & 144.20 & 87.28 \\
\hline & Lysine & 143.24 & 145.18 & 125.75 & 77.93 \\
\hline & Total & 713.22 & 757.65 & 654.44 & 402.62 \\
\hline \multirow{11}{*}{$\begin{array}{l}\text { Nonessential } \\
\text { amino acid }\end{array}$} & Aspartic acid & 97.21 & 113.07 & 106.00 & 57.79 \\
\hline & Serine & 92.11 & 104.09 & 95.14 & 57.61 \\
\hline & Glutamic acid & 209.16 & 262.38 & 245.88 & 159.01 \\
\hline & Glycine & 90.74 & 110.24 & 99.44 & 59.39 \\
\hline & Alanine & 195.81 & 270.94 & 231.99 & 126.11 \\
\hline & Cystine & 45.74 & 57.74 & 49.63 & 19.27 \\
\hline & Tyrosine & 167.96 & 187.92 & 167.37 & 100.56 \\
\hline & Histidine & 67.01 & 68.23 & 60.78 & 35.83 \\
\hline & Arginine & 311.87 & 333.33 & 283.45 & 190.30 \\
\hline & Proline & 219.73 & 290.81 & 273.77 & 125.61 \\
\hline & Total & $1,400.13$ & $1,685.67$ & $1,507.46$ & 873.70 \\
\hline \multirow{18}{*}{$\begin{array}{l}\text { Amino acid } \\
\text { derivative }\end{array}$} & Sarcosine & 26.98 & 84.98 & 71.12 & 22.39 \\
\hline & a-Amino adipic acid & 10.88 & 26.66 & 24.22 & 4.50 \\
\hline & Urea & 19.90 & 33.75 & 33.16 & 0.00 \\
\hline & Phosphoserine & 3.90 & 5.02 & 5.15 & 5.41 \\
\hline & a-Amino-n-butyric acid & 2.25 & 18.00 & 3.24 & 1.51 \\
\hline & Cystationine & 15.91 & 21.62 & 16.84 & 9.93 \\
\hline & B-Alanine & 38.89 & 47.23 & 42.04 & 14.85 \\
\hline & $\beta$-Amino isobutyric acid & 119.28 & 121.55 & 100.13 & 45.25 \\
\hline & y-Amino-n-butyric acid & 34.53 & 37.28 & 32.59 & 17.86 \\
\hline & Ethanol amine & 12.76 & 16.07 & 14.00 & 11.93 \\
\hline & Ammonia & 25.98 & 34.93 & 35.05 & 14.38 \\
\hline & Hydroxylysine & 25.98 & 28.93 & 25.96 & 20.36 \\
\hline & Ornithine & 23.62 & 20.69 & 17.48 & 15.19 \\
\hline & 3-Methyl histidine & 102.07 & 9.13 & 7.68 & 7.16 \\
\hline & Anserine & 126.07 & 125.80 & 120.40 & 33.45 \\
\hline & Carnosine & 6.60 & 9.44 & 7.19 & 5.65 \\
\hline & Total & 595.61 & 641.09 & 556.24 & 229.82 \\
\hline & Total & $2,858.15$ & $3,255.26$ & $2,877.46$ & $1,592.05$ \\
\hline
\end{tabular}

본 연구에서는 무독화 옻 추출물의 농도, 사용 원료와 초산 균이 달라 유리 아미노산 차이가 발생한 것으로 여겨진다. 또한, Choi 등(15)은 우루시올이 제거된 발효 옻 추출물의
유리 아미노산은 24종, 총량은 $3,033.8 \mathrm{mg} / \mathrm{L}$, 주요 유리 아미노산은 alanine $(243.6 \mathrm{mg} / \mathrm{L}), \quad \operatorname{serine}(231.2 \mathrm{mg} / \mathrm{L})$, leucine $(218.6 \mathrm{mg} / \mathrm{L})$ 으로 보고하여, 본 연구에서 제조한 


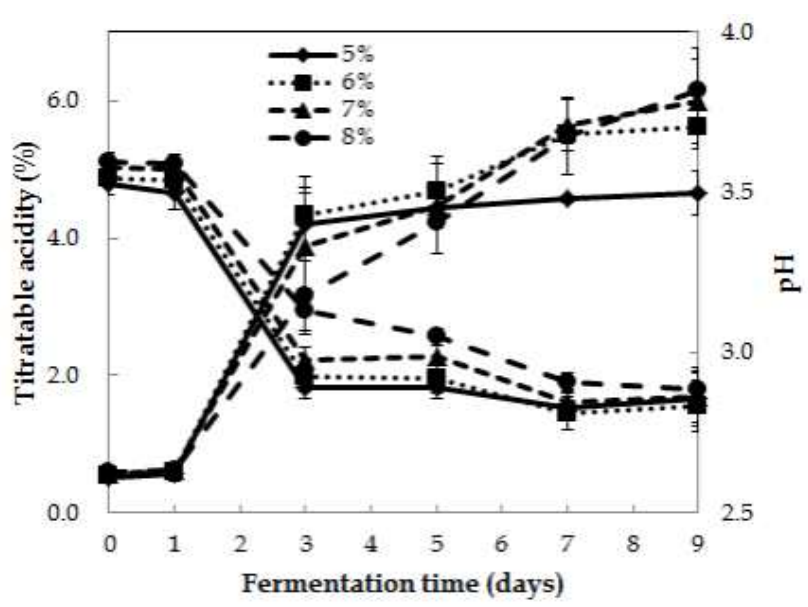

Fig 2. Change in titratable acidity and $\mathrm{pH}$ in acetic fermentation with respect to initial alcohol concentration.

The detoxified Rhus verniciflua vinegar was fermented by static method at $30^{\circ} \mathrm{C}$ for 9 days (content of detoxified Rhus verniciflua extract : $2 \%$, inoculation of vinegar starter : $10 \%)$.

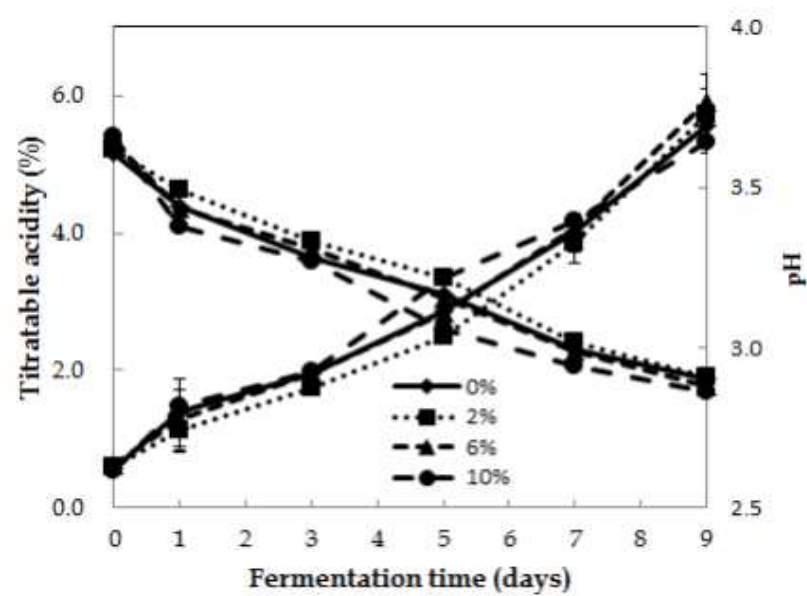

Fig. 3. Change in titratable acidity and $\mathrm{pH}$ in acetic fermentation for detoxified Rhus verniciflua extract concentrations.

The detoxified Rhus verniciflua vinegar was fermented by static method at $30^{\circ} \mathrm{C}$ for 9 days (initial alcohol concentration : 6\%, inoculation of vinegar starter : 10\%).

무독화 옻식초의 유리 아미노산 분석 결과와는 차이가 있었 다. 이는 식초 제조시 옻 추출물의 첨가량, 발효과정에서 미생물에 의해 일부 아미노산의 변화가 일어난 것으로 판단 된다.

\section{요 약}

본 연구에서는 옻의 활용과 부가가치 증대를 위해 우루 시올 성분이 제거된 무독화 옻 추출물을 첨가한 식초제조 조건 및 품질 특성을 조사하였다. 종초 접종량을 달리하여 무독화 옻 추출물 첨가한 식초의 초산 발효에서는 발효 후반 종초 접종량에 따른 산도는 4.8 4.9\%로 차이가 나타나 지 않았다. 초기 알코올 농도에 따른 초산 발효에서는 초기
알코올 농도가 높을수록 산도가 높은 경향을 나타내었으 며, 초산 수율은 $82.8 \%, 84.4 \%, 77.7 \%$ 및 $69.5 \%$ 로, 초기 알코올 농도 $6 \%$ 시험구에서 가장 높았으며, 알코올 $8 \%$ 시험구에서 낮은 것으로 나타났다. 무독화 옻 추출물 농도 에 따른 초산 발효에서는 옻 추출물 첨가한 식초의 산도는 $5.3 \sim 5 \%$ 로 무첨가 식초의 산도 $5.5 \%$ 에 비해 $0.4 \%$ 높았으 며, 옻 추출물 농도에 따른 차이는 크지 않았다. 무독화 옻 추출물 농도에 따른 갈색도는 무첨가 식초가 옻 추출물 첨가 식초보다 갈색의 정도가 높았으며 색도는 옻 추출물 $2 \%$ 첨가 식초의 명도가 가장 높게 나타났다. 무독화 옻 추출물 농도에 따른 주요 유기산은 acetic acid로 분석되었 으며 함량은 $53.3 \sim 65.8 \mathrm{mg} / \mathrm{mL}$ 의 범위를 나타내었다. 무독 화 옻식초의 주요 아미노산은 arginine(190.3 333.3 $\mu \mathrm{g} / \mathrm{mL})$, proline $(125.6 \sim 290.8 \mu \mathrm{g} / \mathrm{mL})$, alanine $(126.1 \sim 270.9 \mu \mathrm{g} / \mathrm{mL})$, glutamic acid(159.0 262.4 $\mathrm{\mu g} / \mathrm{mL})$ 이며, 무첨가 식초에 비해 높은 유리 아미노산은 alanine과 glutamic acid로 나타났다.

\section{감사의 글}

This work was carried out with the support of 'Cooperative Research Program for Agriculture Science \& Technology Development (Project No. PJ00982601)' Rural Development Administration, Republic of Korea.

\section{References}

1. Kwon SH, Jeong EJ, Lee GD, Jeong YJ (2000) Reparation method of fruit vinegars by two stage fermentation and beverages including vinegar. Food Ind Nutr, 5, 18-24

2. Kim DH (1999) Studies on the production of vinegar from fig. J Korean Soc Food Sci Nutr, 28, 53-60

3. Lee WJ, Kim SS (1998) Preparation of Sikhe with brown rice. Korean J Food Sci Technol, 30, 146-150

4. Jeong YJ, Lee MH (2000) A view and prospect of vinegar using Kyungpook special products (persimmon, apple and grape). Food Ind Nutr, 5, 53-59

5. MFDS (2014) Korean Food Standards Codex. Ministry of Food \& Drug Safety, Cheongju, Korea, p 56, 165-166

6. Jung NC (1998) Biological activity of urushiol and flavonoids from Lac tree (Rhus verniciflua Stokes). $\mathrm{Ph}$ D Thesis. Chonnam National University, Gwangju, Korea, p 9-21

7. Kim JB (2003) Identification of antioxidative component from stem bark of Rhus verniciflua. Korean J Food Nutr, 
$16,60-65$

8. Lee JC, Kim J, Lim KT, Jang YS (2002) Identification of Rhus verniciflua Stokes compounds that exhibit free radical scavenging and anti-apoptotic properties. Biochim Biophys Acta, 1570, 181-191

9. Son YO, Lee KY, Lee JC, Jang HS, Kim JG, Jeon YM, Jang YS (2005) Selective antiproliferative and apoptotic effects of flavonoids purified from Rhus verniciflua Stokes on normal versus transformed hepatic cell lines. Toxicol Lett, 135, 115-125

10. Park KY, Jung GO, Lee KT, Choi JW, Choi MY, Kim GT, Jung JJ, Park HJ (2004) Antimutagenic activity of flavonoids from the heartwood of Rhus verniciflua. J Ethnopharmacol, 90, 73-79

11. Lee JD, Huh JE, Jeon GS, Yang HR, Woo HS, Choi DY, Park DS (2009) Flavonol-rich RVHxR from Rhus verniciflua Stokes and its major compound fisetin inhibits inflammation-related cytokines and angiogenic factor in rheumatoid arthritic fibroblast-like synovial cells and in vivo models. Int Immunopharmacol, 9, 268-276

12. Lee DS, Jeong GS, Li B, Park H, Kim YC (2010) Anti-inflammatory effects of sulfuretin from Rhus verniciflua Stokes via the induction of heme oxygenase-1 expression in murine macrophages. Int Immunopharmacol, 10, 850-858

13. Kim JS, Kwon YS, Chun WJ, Kim TY, Sun J, Yu CY, Kim MJ (2010) Rhus verniciflua Stokes flavonoid extracts have anti-oxidant, antimicrobial and a-glucosidase inhibitory effect. Food Chem, 120, 539-543

14. KFS (2008) The investigation of forestry management of Korea. Korea Forest Service, Daejeon, Korea, p 12-19

15. Choi HS, Yeo SH, Jeong ST, Choi JH, Park HS, Kim MK (2012) Preparation and characterization of urushiol free fermented Rhus verniciflua stem bark (FRVSB) extracts. Korean J Food Sci Technol, 44, 173-178

16. Choi HS, Yeo SH, Jeong ST, Choi JH, Kang JE, Kim MK (2012) Effect of the extracts from fermented-Rhus verniciflua stem bark with fomitella fraxinea on the growth and enzyme activity of soybean productfermenting microorganisms. Korean J Mycol, 40, 235-243

17. Choi HS, Kim MK, Park HS, Yun SE, Mun SP, Kim JS, Sapkota K, Kim S, Kim TY, Kim SJ (2007) Biological detoxification of lacquer tree (Rhus verniciflua Stoles) stem bark by mushroom species. Food Sci Biotechnol, 16, 935-942

18. Baek SY, Park HY, Lee CH, Yeo SH (2014) Comparison of the fermented property and isolation of acetic-acid bacteria from traditional Korean vinegar. Korean J Food Preserv, 21, 903-907

19. Chen XH, Lou WY, Zong MH, Smith TJ (2011) Optimization of culture conditions to produce high yields of active Acetobacter sp. CCTCC M209061 cells for anti-Prelog reduction of prochiral ketones. BMC Biotech, 11, 110-121

20. NAAS (2013) Quality analysis manual for fermented food. Semyeongmunhwasa, National Academy of Agricultural Science, RDA, Wanju, Korea, p 93-94

21. Hitachi High-Technologies Corporation. L-8900 Amino Acid Analyzer. (2014) Available from: http://www.hitachihitec.com/global/science/lc/18900.html\#jump2. Accessed

22. Kim YT, Seo KI, Jung YJ, Lee YS, Shin KH (1997) The production of vinegar using citron (Citrus junos Seib) juice. J East Soc Dietary Life, 7, 301-307

23. Jeong YJ, Seo JH, Park NY, Shin SR, Kim GS (1999) Changes in the components of persimmon vinegars by two stages fermentation. Korean J Postharvest Sci Technol, 6, 228-232

24. Seo JH, Jeong YJ, Kim JN, Woo CJ, Yoon SR, Kim DH (2001) Quality comparison of potato vinegars produced by various Acetobacter bacteria. Korean J Postharvest Sci Technol, 8, 60-65

25. Kim MH, Choi UK (2006) Acetic acid fermentation by Acetobacter sp. SK-7 using Maesil juice. Korean J Food Culture, 21, 420-425

26. Hong SM, Kang MJ, Lee JH, Jeong JH, Kwon SH, Seo KI (2012) Production of vinegar using Rubus coreanus and its antioxident activities. Korean J Food Preserv, 19, 594-603

27. Kim YD, Kang SH, Kang SG (1996) Studies on the acetic acid fermentation using maesil juice. J Korean Soc Food Sci Nutr, 25, 695-700

28. Oh YJ (1992) A study on cultural conditions for acetic acid production employing pear juice. J Korean Soc Food Nutr, 21, 377-380

29. Kim KE, Choi OS, Lee YJ, Kim HS, Bae TJ (2001) Processing of vinegar using the sea tangle (Laminaria japonica) extract. Korean J Life Sci, 11, 211-217

30. Woo SM, Yeo SH, Kwon JH, Kim SH, Jeong YJ (2014) Quality characteristics of high-acidity vinegar prepared with grape juice. Korean J Food Preserv, 22, 100-107

31. Lee SW, Kwon JH, Yoon SR, Woo SM, Yeo SH, Jeong YJ (2011) Quality characteristics of brown rice vinegar prepared sing varying amounts of nuruk (an amylolytic 
enzyme preparation) and employing different fermentation conditions. Korean J Food Preserv, 18, 26-32

32. Joo KH, Cho MH, Park KJ, Jeong SW, Lim JH (2009) Effects of fermentation method and brown rice content on quality characteristics of brown rice vinegar. Korean J Food Preserv, 16, 33-39

33. Nakanc S (1988) Food useful for preventing alcohol in toxication containing persimmon-vinegar and optimum fruits, with blood alcohol concentration reducing action. Japan Patent 63, 562-566

34. Woo SM, Jo YJ, Lee SW, Kwon JH, Yeo SH, Jeong
YJ (2012) Quality comparison of static-culture and commercial brown rice vinegars. Korean J Food Preserv, 19, 301-307

35. Woo SM, Yeo SH, Kwon JH, Kim SH, Jeong YJ (2015) Quality characteristics of high-acidity vinegar prepared grape juice. Korean J Food Preserv, 22, 100-107

36. Shin JS, Jeong YJ (2003) Changes in the components of acetic acid fermentation of brown rice using raw starch digesting enzyme. J Korean Soc Food Sci Nutr, 32, 381-387 